\title{
Rhetorically Defining a Social Institution: How Leaders Have Framed Same-Sex Marriage
}

\author{
Dennis C Grube, University of Cambridge
}

Elizabeth van Acker, Griffith University

Questions about the definition, meaning and limits of marriage continue to be a topic of fierce political debate in advanced Western democracies. These arguments have in large part centred on questions concerning same-sex marriage in particular. In jurisdictions like the United Kingdom, Australia, and the United States, politicians from both sides of the political divide have sought to define what marriage means in ways that reflect their own social values. This paper focusses in particular on the leadership of David Cameron in the UK, Barack Obama in the USA and Tony Abbott in Australia, analysing how their rhetoric has sought to privilege different ideational frames for understanding same-sex marriage. In examining the rhetorical choices of these three leaders, the article seeks to combine the insights of 'discursive institutionalism' (Schmidt 2008; 2010) and 'rhetorical political analysis' (Finlayson 2007) to trace how the framework of ideas that underpin marriage has shifted over the past decade.

Schmidt, in outlining the basis for discursive institutionalism, advocates for identifying both the "background ideational abilities that explain the internal processes by which institutions are created' and the "foreground discursive abilities" through which sentient agents may change (or maintain) their institutions following a logic of communication' (Schmidt 2010: 15 - emphasis in original). In applying a discursive institutionalist analysis to debates over same-sex marriage, this article tackles two specific research questions. Firstly, what are the components of the institution of marriage, and how have these changed over time? This will establish the ideational basis of marriage. Secondly, to what extent have political leaders been able to discursively re-shape what marriage means without compromising its ideational and conceptual integrity? This examines the extent to which political leaders can contribute to the discursive re-making of institutions through their own communication abilities.

We argue that rhetorical leadership has been central to defining both the underlying ideas about what marriage is for, and to shaping the arguments about how those values emerge in policy practice. In the process, the institution of marriage has been discursively re-defined. This re-definition has occurred through a gradual rhetorical re-framing that has drawn out internal elements within the institution itself and used them to re-define its core. Cameron legalised same-sex marriage in England and Wales, despite strong opposition from some sections of the Conservative Party, by arguing that the best way to preserve the institution of marriage is to extend it. In the US in 2012, Obama publicly voiced his personal support for gay marriage, presenting the move as essentially a question of rights and 
equality. In Australia, meanwhile, Abbott maintained that marriage remains between 'a man and a woman. ${ }^{1}$

Those aspects of marriage built on 'traditional family values' have been challenged as other values of equality, choice and personal freedom become more important. In effect, marriage has shifted to become more about a loving relationship between two people, whilst traditional aspects that legitimate the creation of children by a man and a woman have receded. The institution of marriage remains intact, and its component parts remain in place, but the relative importance of those component parts has been discursively reframed. As a result, the debates over marriage equality and the continuing importance of traditional marriage have become intertwined.

The sections that follow begin by exploring the theoretical ground covered by the new discursive institutionalism and how it can be applied to study the changing rhetoric of marriage. In the process, the paper outlines how the 'Rhetorical Political Analysis' (RPA) advocated by Finlayson (2007) can help to highlight the relationship between rhetoric and discursive institutions. In particular, we discuss how the different social and political contexts in which each leader operated shaped the argumentative possibilities (an important element of RPA).

\section{Discursive Institutionalism and the Explaining of Change}

Despite their place at the very heart of the political science discipline - or perhaps because of it - fierce disagreement remains over what institutions actually are, and to what extent they can be changed or shaped by the agency of the actors who inhabit them. In order to theorise the ways in which institutions are created and maintained, scholars have devised and debated what are collectively known as the 'new institutionalisms' - rational choice institutionalism, historical institutionalism and sociological institutionalism (see Hall and Taylor 1996; Bell 2011). The critique of these three institutionalisms is that they are better at explaining continuity rather than change. Discursive institutionalism has emerged as a fourth 'new institutionalism' partly to re-insert a sense of dynamism into how institutions change, suggesting that internal boundaries are capable of being re-shaped and renegotiated by the way in which actors communicate ideas (see Schmidt 2008; 2010).

As the work of Schmidt and others has argued (see Hay 2010), ideas provide the building blocks of discourse. It therefore follows that changes in discourse will have an impact on ideas and the shape of the institutions that they spawn. Discursive institutionalism is being applied to study issues as diverse as language consistency in the

\footnotetext{
${ }^{1}$ Abbott was deposed as prime minister by a party-room vote in September 2015, to be replaced by Malcolm Turnbull. Prime Minister Turnbull has previously voiced his personal support for same-sex marriage, but the issue remains one of debate within the governing Coalition. At the time of writing, the current government policy commitment is to hold a plebiscite on same-sex marriage in 2017.
} 
parliamentary reports of Canadian bureaucrats (Dutil and Ryan 2013), and fiscal policy and climate change in Europe and the United States (Hope and Raudla 2012). Discursive institutionalism has also been critiqued as unnecessary by those, like Bell (2011), who suggest that an agency-centred form of historical institutionalism is more effective in explaining both change and stasis.

For the purposes of this paper, discursive institutionalism offers a useful lens for examining how changing ideas about the nature of marriage have contributed to re-shaping the institution in the twenty-first century. An historical-institutionalist approach - even an agency-centred one - does not provide the same analytical purchase when examining the extent to which a social institution like marriage is able to change shape without necessarily breaking its existing structures. Arguably, there has been no particular exogenous shock, or 'critical juncture' that has forced institutional change upon marriage in an historicalinstitutionalist sense. What has changed is the way that the content of the institution has been discursively framed. Specifically, the focus here is on the role that rhetoric has played in bringing about this change by drawing existing aspects of marriage more to the fore in ways that make room for same-sex marriage without fundamentally altering the nature of what marriage is.

We do not argue that the words of leaders alone can deliver social change. Political leadership may play an important role in how particular issues are discursively framed, but self-evidently the voice of a president or prime minister is not the only persuasive influence within wider policy debates. In exploring how leaders in Australia, the USA and the UK have spoken about same-sex marriage, we are not arguing for a direct causal link between their words and a specific outcome. At best their words are a necessary but not sufficient condition to bring about change. The goal is to analyse, through RPA, the kind of rhetorical approaches that leaders deploy in attempting to pursue particular arguments for or against institutional change.

Leaders are undoubtedly influenced by the wider context within which they find themselves. In each case examined here, there were already well-established movements for marriage reform, which effected the tone and impact of the rhetorical choices made by Cameron, Abbott and Obama as they added their voices to that mix. In the USA, pro samesex marriage groups had pursued a strategy of seeking to establish their marriage rights through the courts as the only way of challenging the opposing and powerful traditional marriage movement. In the UK, Tony Blair's Labour government had advanced the policy debate by introducing civil partnerships, ushering in a more tolerant climate in which Cameron could subsequently frame his arguments supporting same-sex marriage. In Australia, marriage laws are centrally enshrined in the constitution within the jurisdiction of the Commonwealth Government; therefore campaigns for change have focussed mainly on securing a conscience vote in the federal parliament rather than pursuing the matter through the courts. 
At its core, rhetoric is a tool of persuasion. As outlined by Aristotle over two millennia ago, rhetoric allows a speaker to utilise their ethos, logos and pathos to connect with an audience and persuade them to support a particular point of view (see Finlayson 2012). There is now an emerging body of literature on the role played by political rhetoric in states governed by parliamentary systems (Uhr and Walter 2014; 2015; Toye 2011; Kane and Patapan 2010; Bennister 2013; Grube 2011; Atkins et al 2014). This complements the much larger and longer established literature in the US, which focusses on the rhetorical power of the presidency (Tulis 1987; Kernell 2006; Medhurst 2006; Friedman and Friedman 2012), and the ways in which rhetoric frames political debates (Druckman 2004; Lakoff 2004).

In the UK context, scholars have begun examining how rhetorical arguments play an important part not just in communicating ideas but in actually forming their content. In other words, the language chosen in communicating an idea has embedded within it certain frames and beliefs that work to shape the idea. 'To believe something is to accept the (many kinds of) reasons that can be presented for so believing it; to present and explain a belief to others is to present the arguments that are part and parcel of the belief' (Finlayson 2007: 551). This has led Finlayson, along with co-authors like Atkins and Martin (Finlayson 2007; Finlayson and Martin 2008; Atkins and Finlayson 2013; Atkins et al 2014) to advocate a form of 'Rhetorical Political Analysis' (RPA) to understand how political ideas are expressed as political arguments through rhetoric.

RPA conceives politics as the 'arena' in which there is an element of 'ineradicable contestation' as actors utilise arguments to persuade others about the virtue of particular ideas or proposed courses of action (Finlayson 2007: 552). 'To study these arguments, Finlayson suggests a wide array of conceptual tools, including: studying the context within which rhetoric is used; how a problem is 'framed' (see Lakoff 2004); what kind of narrative is promulgated to tell the story; whether arguments are based on logic, emotional appeals, or the authority of the speaker; and how metaphor is deployed (Finlayson 2007: 554-559).

The conceptual tools outlined in RPA offer opportunities for discursive institutionalists, who argue that ideas form the basis of all institutions, to examine the central role of rhetoric in shaping and re-shaping those ideas through argument and debate, and in the process re-shaping the institution itself. In essence RPA shares an epistemology with discursive institutionalism, whilst providing a more defined method. Both see agents as having the power to define institutions, rather than the other way around, and both see argument and persuasion as central to the shaping of ideas. RPA provides methodological guidance by identifying the factors - context, performance, narrative choices - that will influence whether or not any one argument is likely to be persuasive. In this context then, RPA can usefully be allied with discursive institutionalism to capture the extent to which persuasive communication - in the form of rhetoric - is central to allowing agents to discursively re-shape a social institution like marriage. 
It is not suggested here that RPA is essentially an add-on to discursive institutionalism, but rather that rhetoric is one of the building blocks of discursive institutions. If Schmidt is right that institutions are essentially ideational constructs, then the challenge becomes to devise a range of analytical forms through which to understand how those institutions are formed and how they change. As Schmidt notes, there are many versions of discourse analysis already being used. The analysis that follows seeks to demonstrate that RPA can be employed as one such tool for investigating the construction of social institutions, where much rests on how political leaders choose to rhetorically frame the moral values underpinning a particular policy position.

Marriage offers a unique site for this type of analysis because of its particular characteristics. Unlike 'bricks and mortar' institutions, marriage has no specific leaders or governance arrangements. Its incumbents choose to run their marriages in many different ways, according to diverse customs, laws and beliefs. Its legal boundaries are in some cases enshrined in legislation going back centuries, and its local manifestations are embedded in different cultural practices. As an institution without leaders, marriage offers distinctive opportunities for political and community leaders to shape the institution through the power of their rhetoric. Utilising RPA as a method, and applying it through the lens of discursive institutionalism as theory, we argue that the rhetorical leadership of key political actors has been central to re-defining marriage by re-ordering the ideas that underpin it.

In order to analyse the role that rhetorical leadership can play in defining public institutions like marriage, the article adopts a multi-case comparative design. The UK, Australia and the US represent three advanced, western liberal democracies, with similar cultural traditions about the place and role of marriage in society. In each, marriage is celebrated as a secular institution, but one which retains very close links to its religious foundations. This incorporates Christian foundations and understandings, drawing on their shared strong cultural and historical traditions. This has particular consequences for the content of political debates, because strong Christian beliefs are perceived as an important predictor of attitudes towards same-sex marriage in all three jurisdictions (see Baunach 2012: 365; Sherkat, de Vries, and Creek 2010; Nguyen 2015; Clements 2014: 240).

Equally, these three cases offer variations in governance systems that allow us to draw out the tensions between the rhetorical power of leaders, and the institutional authority they possess. Pierceson (2014) argues persuasively that political and legal institutions are an important explanatory variable in determining whether or not a jurisdiction ultimately legislates in support of same-sex marriage. For example, in England and Wales, the prime minister was able to legalise same-sex marriage through a vote of the UK parliament. In Australia, the federal government has constitutional responsibility over marriage law, giving a prime minister great power to block or allow change provided they can maintain majority support in the parliament. In the US, marriage law remains a matter for individual states, rendering the formal authority of the president inadequate to mandate 
change, no matter how persuasive their rhetoric. Indeed, it ultimately took a 2015 decision of the Supreme Court to make a uniform national pronouncement in favour of marriage equality as a constitutional right.

In order to examine these case studies, we select as our data source the public statements and writings of Obama, Cameron and Abbott. Each of them undoubtedly also expressed arguments in discussion with close confidants and advisors, but by focussing on their public words the analysis is able to examine which rhetorical choices they made that might be able to influence the wider public discourse. Before turning to these case studies, the next section first briefly discusses how the meaning of marriage has evolved over time.

\section{The Meaning of Marriage}

Marriage is not a historically fixed institution and its meaning and its purpose has altered dramatically over time. In past centuries, marriage was organised as a public institution which worked for the common and social good and for the benefit of families and society. Marriage was based on factors such as financial considerations, the exchange of property, or to strengthen family connections and political advantage. However, by the eighteenth and nineteenth centuries as industrial society grew and the notion of romance spread through novels and other discourses, the values of love and mutual support became more closely associated with marriage. Romantic love became prominent as an important measure of symbolic exchange (Luhmann 1986; Stone 1977). The allure of marriage flourished, not only because it 'identified with the emotional security of regular companionship' but because marriage offered 'promises of romance and intimacy' (Shumway 2003: 229). The emotional life of marriage became linked to the myth of 'living happily ever after' which is a significant factor in modern cultures and relationships for both women and men. Marriage was also recognised as the ideal institution for providing security and nurturing children.

Although feminist scholars (Okin 1989) often portrayed marriage as a symbol of women's oppression, gender relations have changed significantly in recent decades as couples have increasingly brought emotional expectations to marriage based on love and the ideal of lifelong monogamy and intimacy (Coontz 2005). The laws underpinning marriage have also shifted significantly over the past two centuries, with women no longer denied legal rights to property ownership or considered as their husbands' property. There is also greater acceptance of sexual freedom and equality for women, as well as for samesex couples, with less concern about 'immoral' values.

Same-sex marriage has emerged in the past decade as an inherently disruptive challenge to 'traditional' meanings of marriage (see Johnson 2013). As such, it has become a site for discursive contestation about just what marriage in fact is, as well as what it might become. A study by Olsen (2014) of the arguments used for and against same-sex marriage 
in Connecticut highlighted how 'narratives' were used by proponents of change to tell 'stories' which could make a case for change framed within several different types of rhetorical appeal. These included stories of 'love and legitimacy' to demonstrate that samesex couples did not threaten traditional values, as well as stories based on 'rights' that were being denied through opposing same-sex marriage. Olsen's study suggests that personal stories have the effect of humanising a debate and are more likely to sway an audience than recourse to other forms of evidence. This reflects other research suggesting that social contact with same-sex attracted people makes individuals more likely to support same-sex marriage in many cases (see Burnett and King 2015). Both factors were reflected in the rhetoric of Cameron and Obama as they sought to explain their support for same-sex marriage through personal narratives about people they had met or worked with. We turn now to examining their rhetorical choices in more detail below.

\section{David Cameron - United Kingdom}

In coalition with the Liberal Democrats following the 2010 election, Cameron advanced two simultaneous debates on marriage questions. Firstly, he supported the exploration of ways to give tax breaks to married couples, as foreshadowed in the 2010 Manifesto. Secondly, he set out the case for expanding the institution of marriage to include same-sex couples. He presented the latter not simply as an act of equality, but as the natural extension of a conservative ideology that recognised the power of marriage to hold society together. In his 2011 speech at the Conservative Party conference, Cameron said:

... Yes, it's about equality, but it's also about something else: commitment. Conservatives believe in the ties that bind us; that society is stronger when we make vows to each other and support each other. So I don't support gay marriage despite being a Conservative. I support gay marriage because I'm a Conservative (Cameron 2011a).

Cameron underlined his case by suggesting that marriage is 'not just a piece of paper. It pulls couples together through the ebb and flow of life. It gives children stability. And it says powerful things about what we should value' (Cameron 2011a).

The debate within the Conservative Party over the question of same-sex marriage was long and at times acrimonious, even after a bill to allow same-sex marriage passed its second reading in the House of Commons on 5 February 2013. Some 134 of the party's MPs opposed the bill in Parliament, including Cabinet Ministers Owen Paterson and David Jones. Backbencher Tim Loughton accused the government of doing a 'grubby deal' with the Opposition to pass the bill (cited in Watt 2013). The Chair of the Conservative Grassroots group, Bob Woollard argued that 'family lies at the heart of Conservative values. .... The golden inheritance of every previous generation, that has been lovingly handed down to us, 
is being smashed on the anvil of "equality and fairness"' (cited in Dominiczak and Malnick 2013).

In contrast, the Prime Minister continued to focus on the way that the new law actually upheld and strengthened the value of marriage as a central social institution within British society. In Pink News in July 2013, he stressed the importance of 'commitment' as a value:

I am proud that we have made same-sex marriage happen. I am delighted that the love two people have for each other - and the commitment they want to make - can now be recognised as equal. I have backed this reform because I believe in commitment, responsibility and family. I don't want to see people's love divided by law. (Cameron 2013a)

The Churches opposed same-sex marriage, warning that it reduced the status of marriage and would harm families. A Catholic bishop accused Cameron of being 'devoid of moral competence' (cited in Johnson 2012). In response, the Prime Minister's rhetoric worked to define marriage within a wider tradition of British values: 'there is something special about marriage ... the values of marriage are give and take, support and sacrifice values that we need more of in this country' (Cameron 2013b). Cameron suggested that marriage was an unsurpassed model which he wanted everyone to embrace as 'a good thing for our country - it's the ultimate form of commitment under the law - and we want to show our support for it' (Cameron 2013b).

In summary, Cameron's rhetoric in the first term of his prime ministership applied arguments grounded in values and traditions which enabled him to position support for same-sex marriage as being consistent with the conservative values of his party. He drew on ideas endogenous to established traditions of marriage as an institution central to social stability and cohesion. He then communicated those ideas in a way that shaped support for same-sex marriage as being a natural extension of conservative values. Instead of seeking to specifically rebut other endogenous components of traditional marriage - such as those centred on the biological pairing of a man and a woman - Cameron was able to shift the definitional debate simply by privileging those parts of the institution that favoured his arguments.

Applying the tools of RPA provides some level of explanation about why Cameron adopted this approach. He understood the rhetorical context in which he was operating. As the leader of the Conservative party, itself riven between its more socially progressive and determinedly conservative wings, Cameron had little choice but to frame his case for samesex marriage in conservative terms. His freedom of rhetorical action - the palette from which he could choose his colours - was restrained by the values, traditions, and ideological positions of his party. But having chosen an inherently conservative frame, his narrative 
was relentlessly positive, focussing on the societal benefits of an institution centred on concepts like commitment and love. By taking the 'positive' ground in the debate he isolated opponents as presenting arguments based on fear - warnings that society would crumble in the face of change. But by framing those positive arguments in traditionally conservative terms - commitment, responsibility, family - he took the rhetorical sting from opponents seeking to portray him as a dangerous radical trying to change the fabric of 'British values.'

\section{Barack Obama - US}

By comparison with Cameron, Obama was relatively silent on the issue of same-sex marriage during much of his first presidential term. However his rhetoric on same-sex marriage changed significantly over the course of his political career. As a Senator for Illinois in 2006 in a floor statement to the Senate, he stated his belief that 'marriage is between a man and a woman' but added that gay couples should have the right to visit their partners in hospital and be able to share health care. They 'should be treated with dignity and have their privacy respected by the federal government' (Obama 2006). He added that marriage matters should be left to the states. Although he offered support for civil unions, in 2008 he repeated his definition of marriage as 'the union between a man and a woman' in an interview with Rick Warren at the Saddleback Church. He also repeated his position that same-sex marriage was a state issue, but that he supported state-recognised civil unions (cited in CNN 2008). In his acceptance speech at the Democratic National Convention in 2008, he reiterated his view that 'our gay and lesbian brothers and sisters deserve to visit the person they love in the hospital and to live lives free of discrimination' (Obama 2008).

As President, Obama's rhetoric was characterised by some public wrestling with his private conscience. He emphasised that:

my feelings about this are constantly evolving. I struggle with this. I have friends, I have people who work for me, who are in powerful, strong, longlasting gay or lesbian unions. And they are extraordinary people, and this is something that means a lot to them and they care deeply about. (Obama 2010)

The matter came to a head for the Obama administration in May 2012 when VicePresident Joe Biden appeared on NBC's 'Meet the Press', declaring his full support for samesex marriage at a time when Obama had not publicly favoured it. A few days later, in an interview with $A B C$ news, Obama for the first time announced his support for gay marriage, whilst admitting that Biden's declaration had pushed him into revealing his own stance earlier than he had planned.

I think about members of my own staff who are in incredibly committed monogamous relationships, same-sex relationships, who are raising kids 
together; when I think about those soldiers or airmen or marines or sailors who are out there fighting on my behalf and yet feel constrained, even now that 'don't ask, don't tell' is gone, because they are not able to commit themselves in a marriage, ... I think same-sex couples should be able to get married. (Obama 2012)

Following his re-election in November 2012, the president's rhetoric strengthened. In his second inauguration address in January 2013 he argued that the nation's journey 'is not complete until our gay brothers and sisters are treated like anyone else under the law, for if we are truly created equal, then surely the love we commit to one another must be equal as well' (Obama 2013).

Obama's support for the legal and human rights frame was evident when he warmly welcomed the decision of the United States' Supreme Court in June 2015 in the case of Obergefell $v$. Hodges that established a fundamental constitutional right for same-sex couples to marry. First he tweeted that 'Today is a big step in our march toward equality. Gay and lesbian couples now have the right to marry, just like anyone else'. He re-affirmed those views in a statement only hours after the ruling, in which he said:

Our nation was founded on a bedrock principle that we are all created equal... the Supreme Court recognized that the Constitution guarantees marriage equality. In doing so, they've reaffirmed that all Americans are entitled to the equal protection of the law. That all people should be treated equally, regardless of who they are or who they love (Obama 2015).

In summary, Obama strove to rhetorically frame changes in the definition of marriage by arguing that it was in the national interest and a reflection of established American values. He moved the debate away from discussions about fatherhood and whether marriage should remain between 'a man and a woman', and into the arena of debates about freedom and equality. By focussing first on the laudable characteristics of people who were fighting for the military, or raising families, he positioned the debate around the legitimate rights of patriotic Americans who happened to be non-heterosexual in choosing who they loved. Just as Cameron was able to rhetorically link same-sex marriage to core Conservative party values about family stability, Obama was able to rhetorically link it to wider American values about equal rights and opportunity.

Obama's tentative initial steps reflected the evolution of the rhetorical context in which he was operating, and the frames and narratives available to him. As a candidate for the presidency, and then a first-term president, the need to maintain a broad-base of voter support meant that the course of least resistance was to prevaricate on the issue and simply assert that - whatever his personal views - it was a matter for the states. This essentially legalistic argument suited the initial rhetorical context. As a second-term president, that 
context changed. Freed from the need to run for office again, Obama was able to strengthen his views, positioning himself ultimately as a cheerleader in support of the 2015 Supreme Court decision.

The narrative he constructed around marriage equality moved from the pragmatic earlier formulation (it's a matter for the states) to an argument grounded in human rights, underpinned by emotional connection with the impact of changes for same-sex attracted people. That emotional appeal was premised on assertions about people's constitutional rights - reassuring Americans that this was not a radical departure but an embrace of established American legal values.

\section{Tony Abbott - Australia}

In Australia, Abbott persistently defined the limits of marriage as being about heterosexual unions, promoting a particular view of family life based on traditional family values. As Opposition leader in 2012, Abbott joined the majority of MPs in the Australian parliament in opposing a private members bill in support of same-sex marriage. Following the debate, Abbott forced one Opposition frontbencher to resign for suggesting that supporting gay marriage might lead to eventual endorsement of bestiality (see Packham and Kerr 2012). In the lead up to the 2013 election, with the Liberal Party well ahead in the polls, attention began to focus more directly on what an Abbott prime ministership might mean for moral questions in general, and for same-sex marriage in particular.

On the John Laws radio show in August 2013, Abbott maintained a very traditional line. 'I have always been completely consistent on this. I support the traditional definition of marriage as between a man and a woman and that's where I will be' (Abbott 2013b). Abbott rhetorically positioned his stance not as a question of opposing equality, but rather as staying true to broader conservative ideals of evolutionary rather than revolutionary change. '...I'm not saying that our culture and our traditions are perfect. But we have to respect them and my idea is to build on the strength of our society and I support by and large evolutionary change. I'm not someone who wants to see radical changes based on the fashion of the moment' (Abbott 2013b). Asked about his comments, he did not rule out that the law might one day change, but he was unwilling to countenance it as something likely to happen in the near future. 'If this country lasts for a thousand years quite possibly at some point we might be a republic, but I don't think a republic is inevitable anytime soon and similarly I don't see same-sex marriage as inevitable' (cited in Griffiths 2013).

The issue came to a head for the newly elected Abbott government late in 2013 following the successful passage through the parliament of the Australian Capital Territory (ACT) of an act allowing same-sex marriage within that jurisdiction. In receipt of legal advice suggesting that the ACT in fact had no power to legislate in the area of marriage, the Abbott 
government launched a High Court challenge. In framing the reasoning behind this, Abbott was careful to insist that it was a question of constitutional rights rather than an attempt to impose a moral judgement. For example, in a radio interview he insisted that the fight was a 'legal one' and that 'it's not a question of being for or against gay marriage, it's a question of adhering to the Constitution'. He described himself as 'a traditionalist': 'from time immemorial in every culture that's known marriage, or that kind of solemnised relationship, has been between a man and a woman' (Abbott 2013).

In summary, Abbott staked out a clear position as opposition leader and then prime minister against supporting same-sex marriage. When confronted with debates on the issue, his rhetoric focussed on fixed definitions of marriage centring on the relationship between a man and a woman. To defend the institution against change, he rhetorically privileged those aspects of the institution connected with gender and religion, rather than those parts connected with loving relationships. Abbott effectively kept his contributions to the debate focussed on a particular conception of what marriage is by positioning discussion of same-sex marriage as a debate about tradition and legal definitions rather than a debate about equality.

A 'rhetorical political analysis' on Abbott's stance is enlightening. Abbott was clearly aware of the rhetorical context in which he was operating. As an avowed conservative on an issue which polling suggests an overwhelming majority of the public support, Abbott was keen not to amplify same-sex marriage as an issue. He kept his rhetoric short and clear, relying on a legalistic constitutional argument for overturning the ACT's same-sex marriage laws rather than making a case from first-principals based on moral values. He defended the traditional definition of marriage - between a man and a woman - but constructed the narrative around his position on the need to support 'evolutionary' rather than 'revolutionary' change. In short, he was careful not to invoke emotional arguments about societal damage that might result from embracing change, resorting instead to broader and less confronting arguments around policy evolution.

\section{Analysis: Discursively Shaping the Meaning of Marriage}

The shape of marriage debates has changed dramatically across the western world over the past two decades. Liberal democracies are confronting the 'deinstitutionalization' of marriage where many of the norms that once guided marriage have been weakened or reshaped as societies become increasingly secular and legal institutions recognise a diversity of family types (Cherlin 2004). These changes have also fed into broader debates around contemporary social change and perceptions about the transformation and weakening of social structures that socialise individuals and transmit norms and values (Beck and BeckGernsheim 2002; Giddens 1992). 
Against this background, rhetorical choices made by leaders when communicating about the institution of marriage are significant in determining which aspects are given precedence in public debate. In choosing whether to frame marriage as an institution based on traditional family values, or as a modern institution whose defining feature is love between two people, or a legally defined institution involving a man and a woman, leaders are giving discursive shape to what marriage actually is. They are doing so within a context of changing public attitudes towards marriage which have become increasingly liberal according to opinion polls and as indicated by the increasing numbers of children born outside marriage and trends in cohabitation rates (van Acker 2017).

In the cases examined here, the discursive contestation occurred around fundamentally different stances on the role of institutions in society. For conservatives like Cameron and Abbott, institutions provide the basis for societal stability, including specifically the institution of marriage. This meant that the core meaning of marriage should not be altered. Their point of difference was on whether the core conservative idea underpinning the institution was about the commitment of two people to each other, or specifically the union between a man and a woman. For Obama, the argument was not about the centrality of institutions to society, but rather the centrality of human rights and protections as underpinning harmonious social existence. Accordingly, instead of arguing that marriage was an institution that needed to be preserved, he was able to argue for a rights-based view of marriage which emphasised the equal rights of two people to be able to institutionalise their love through marriage.

Applying the analytical approach advocated by RPA, the contestation between competing arguments about the meaning of marriage gives shape to the ideas that underpin the arguments. In other words, it is only by evaluating the rhetorical power of the arguments that we can understand the ideas that they seek to convey. In the US, Obama has pursued arguments grounded in inclusion, equality, freedom and the national interest. Those arguments have given shape to his idea of what marriage is, by defining it in debate against those who argue for a more restrictive definition.

Jakobsen and Pellegrini (2009) argue that Obama could have moved the debate toward the post-partisan ground that he is well known for staking out on other issues. Such a move could have been accomplished not by invoking his religious views, but by pointing to the need to protect religious freedom by removing the state's role in religious marriage (Jakobsen and Pellegrini 2009: 1232-1233). Cohen (2012) argues that same-sex marriage is a continuation of the hegemonic system, which she refers to as the 'neoliberal normative underpinnings of same-sex marriage'. Cohen refers to Obama's 2012 ABC interview as confirmation of Obama's commitment to neoliberal ideology and the protection of individual rights. This is in contrast to his ardent support for fatherhood programs, reflected in speeches about his childhood experiences of an absent father and the importance for men to not abandon their children (see Obama 2014; cf. Gonzalez 2014). In the UK, 
however, Cameron focussed less on universal values and human rights than on the importance of maintaining marriage as a strong social institution by expanding its reach to all those who might wish to join, whatever their sexual preference. What we see is an amalgamation of liberalism's support for individual rights and equality and conservatism's celebration of stable families. At the same time, as Hayton (2010) argues, legalising samesex marriage gave Cameron an opportunity to broaden the appeal of the Conservative Party by giving it a more modern edge on a key social issue.

In discursive institutionalist terms, Cameron and Obama used their communicative abilities to draw forth those parts of the background values underpinning marriage that they wished to privilege through argument. They used their 'background ideational abilities' (Schmidt 2008) to construct their view of what marriage is, but it was only when communicating through their 'foreground discursive abilities' that those views were given the persuasive power to actually shape the institution of marriage as they would wish. Both Cameron and Obama demonstrated the ability to communicate a different vision of marriage that re-shaped the institution in the eyes of the public. Just as importantly, they achieved this by drawing on endogenous factors and components of marriage. This enabled them to frame change as being entirely consistent with the institution as it already exists, rather than having to argue that the institution itself is in some way broken.

By contrast in Australia, Abbott used his rhetorical power as prime minister (see Grube 2013) to maintain a narrow definition of marriage by focussing on one central component of the established institution - namely that it should be between a man and a woman. As Finlayson argues (2007), it is only through argumentation in contested debates that political actors are able to test the strength of the ideas and traditions upon which institutions are based. In the Australian case, at the time of writing, the arguments in favour of a narrower definition of marriage are being confronted by the arguments of opponents seeking to draw out the broader components of marriage that appeal to ideas of love, acceptance and companionship. It remains to be seen whether that narrower definition of marriage will withstand significant bi-partisan pressures for change.

What the work of Toye (2010), Tulis (1987), and (Grube 2013) demonstrates, is that rhetoric is in and of itself an institutional power that leaders can use to influence policy outcomes. Their leadership positions guarantee them a hearing, and strategic use of their rhetorical power allows leaders to frame and re-frame policy debates in ways that can actually change the content of those debates. Context always remains a constraining factor, and there is no suggestion here that rhetoric is both a necessary and a sufficient condition to bring about change. Rather, we suggest that the rhetoric of leaders can play a crucial role in shaping the kind of discursive institutions that Schmidt outlines, as has occurred around the issue of same-sex marriage. 


\section{References:}

Abbott, T. 2013. Transcript of the Prime Minister The Hon. Tony Abbott MP, Interview With Neil Mitchell, 23 October, Radio 3aw, Melbourne. URL < http://parlinfo.aph.gov.au>. Consulted 21 May 2015.

Abbott, T. 2013b. Transcript of interview with John Laws, 2SM Sydney, 14 August 2013. URL <http://parlinfo.aph.gov.au>. Consulted 29 July 2015.

Atkins, J. and Finlayson, A. 2013. '...A 40-Year-Old Black Man Made the Point to Me': Everyday Knowledge and the Performance of Leadership in Contemporary British Politics. Political Studies 61: 161-77.

Atkins, J., Finlayson, A., Martin, J., and Turnbull, N. eds. 2014. Rhetoric in British Politics and Society. Basingstoke: Palgrave Macmillan.

Baunach, D. M. 2012. Changing Same-Sex Marriage Attitudes in America from 1988 Through 2010. Public Opinion Quarterly 76: 364-378.

Beck, U. and Beck-Gernsheim, E. 2002. Individualization: Institutionalized Individualism and its Social and Political Consequences. London: Sage.

Bell, S. 2011. Do We Really Need a New 'Constructivist Institutionalism' to Explain Institutional Change? British Journal of Political Science 41: 883-906.

Bennister, M. 2013. Tony Blair's Oratory. In R. Hayton and A. Crines, eds. Labour Party Oratory from Bevan to Brown. Manchester: Manchester University Press.

Burnett, C. M. and King, A. S. 2015. The Personal Politics of Same Sex Marriage. Politics and Policy 43: 586-610.

Cameron, D. 2011a. Conservative Party Conference Speech, Manchester, 5 October 2011. URL < http://www.bbc.com/news/uk-politics-15189614>. Consulted 24 July 2015.

Cameron, D. 2011b. Speech Following UK Riots, 15 August 2011. URL <http://www.newstatesman.com/politics/2011/08/society-fight-work-rights>. Consulted 24 July 2015.

Cameron, D. 2013a. I am so proud we have had the courage to make love equal. Pink News, 18 July 2013. URL <http://www.pinknews.co.uk/2013/07/18/exclusive-i-am-so-proud-wehave-had-the-courage-to-make-love-equal-by-david-cameron/>. Consulted 24 July 2015. 
Cameron, D. 2013b. Marriage is Good for Britain. Mail Online, 27 September 2013. URL <http://www.dailymail.co.uk/debate/article-2435723/DAVID-CAMERON-Marriage-goodBritain--thats-Im-backing-tax-break.html>. Consulted 23 July 2015.

Cameron, D. 2014. When people's love is divided by law, it is the law that needs to change. Pink News, 28 March 2014. URL <http://www.pinknews.co.uk/2014/03/28/davidcameron/>. Consulted 23 July 2015.

Cherlin, A. 2004. The Deinstitutionalization of American Marriage. Journal of Marriage and Family 66: 848-861.

Clements, B. 2014. Partisan Attachments and Attitudes Towards Same-Sex Marriage in Britain. Parliamentary Affairs 67: 232-244.

CNN. 2008. Live Event/Special, Saddleback Presidential Candidates Forum, Aired 16 August 2008. URL <http://edition.cnn.com/TRANSCRIPTS/0808/16/se.02.htm>. Consulted 28 July 2015.

Cohen, C. J. 2012. Obama, Neoliberalism, and the 2012 Election. Souls: A Critical Journal of Black Politics, Culture, and Society 14: 19-27.

Conservative Manifesto. 2010. Invitation to Join the Government of Britain. URL $<$ http://www.general-election-2010.co.uk/2010-general-election-manifestos/ConservativeParty-Manifesto-2010.pdf>. Consulted 31 July 2015.

Coontz, S. 2005. Marriage, A History: From Obedience to Intimacy or How Love Conquered Marriage. New York: Viking.

Dominiczak, P. and Malnick, E. 2013. New Tory Grassroots Battle Over Gay Marriage; Gay Marriage Betrays Family Values, Tories Warn Cameron. The Sunday Telegraph, 2 June 2013, p. 3.

Druckman, J.N. 2004. Political Preference Formation: Competition, Deliberation and the (ir)relevance of Framing Effects. American Political Science Review 98: 671-686.

Dutil, P.A. and Ryan, P.M. 2013. The Bonds of Institutional Language: A Discursive Institutionalist Approach to the Clerk of the Privy Council's Annual Report. Canadian Public Administration 56: 26-46.

Finlayson, A. 2007. From Beliefs to Arguments: Interpretive Methodology and Rhetorical Political Analysis. British Journal of Politics and International Relations 9: 545-563.

Finlayson, A. 2012. Rhetoric and the Political Theory of Ideologies. Political Studies 60: 751767. 
Finlayson, A. and Martin, J. 2008. 'It Ain't What You Say...': British Political Studies and the Analysis of Speech and Rhetoric. British Politics 3: 445-64.

Friedman, J. and Friedman, S. 2012. Rethinking the Rhetorical Presidency. Abingdon: Routledge.

Giddens, A. 1992. The Transformation of Intimacy: Sexuality, Love and Eroticism in Modern Societies. Cambridge: Polity Press.

Gonzalez, M. 2014. President Obama's My Brother's Keeper initiative downplays a crucial factor: marriage. 4 March 2014. URL

<http://www.nationalreview.com/article/372449/marriage-imperative-mike-gonzalez>. Consulted 30 July 2015.

Griffiths, E. 2013. Tony Abbott denies saying Same-Sex Marriage is Fashion of the Moment. ABC News, 13 August 2013. URL <http://www.abc.net.au/news/2013-08-14/abbott-deniessaying-gay-marriage-is-the-fashion-of-the-moment/4886922>. Consulted 30 July.

Grube, D. 2013. Prime Ministers and Rhetorical Governance. Basingstoke: Palgrave Macmillan.

Grube, D. 2011. Speech Cycle? 'Election-defining rhetoric' in Westminster democracies. Australian Journal of Political Science 46: 35-52.

Hall, P. A. and Taylor, C. R. 1996. Political Science and the Three New Institutionalisms. Political Studies 44: 936-957.

Hardin, R. 1982. Collective Action. Baltimore: Johns Hopkins University Press.

Hay, C. 2010. Ideas and the Construction of Interests. In R. H. Cox and D. Beland, eds. Ideas and Politics in Social Science Research. Oxford: Oxford University Press.

Hayton, R. 2010. Conservative Party Modernisation and David Cameron's Politics of the Family. The Political Quarterly 81: 492-500.

Hope, M. and Raudla, R. 2012. Discursive Institutionalism and Policy Stasis in Simple and Compound Polities: The Cases of Estonian Fiscal Policy and United States Climate Change Policy. Policy Studies 33: 399-418.

Jakobsen, J. and Pellegrini, A. 2009. Obama's Neo-New Deal: Religion, Secularism, and Sex in Political Debates Now. Social Research 76: 1227-1254.

Johnson, C. 2013. Fixing the Meaning of Marriage: Political Symbolism and Citizen Identity in the Same-Sex Marriage Debate. Continuum 27: 242-253.

Johnson, S. 2012. Bishop Launches Attack on David Cameron Over Gay Marriage. Daily Telegraph, 9 December 2012. URL 
<http://www.telegraph.co.uk/news/religion/9732704/Bishop-launches-attack-on-DavidCameron-over-gay-marriage.html>. Consulted 30 July 2015.

Kane, J. and Patapan, H. 2010. The Artless Art: Leadership and the Limits of Democratic Rhetoric. Australian Journal of Political Science 45: 371-389.

Kernell, S. 2006. Going Public: New Strategies of Presidential Leadership (4 ${ }^{\text {th }}$ edn). Thousand Oaks: CQ Press.

Lakoff, G. 2004. Don't Think of an Elephant. Vermont: Chelsea Green Publishing.

Luhmann, N. 1986. Love as Passion. Cambridge: Polity Press.

Mackay, F., Monro, S. and Waylen, G. 2009. The Feminist Potential of Sociological Institutionalism. Politics and Gender 5: 253-262.

Mahoney, J. and Thelen. K. 2010. Explaining Institutional Change: Ambiguity, Agency and Power. Cambridge: Cambridge University Press.

March, J. G. and Olsen, J. P. 1989. Rediscovering Institutions: The Organizational Basis of Politics. New York: The Free Press.

Medhurst, M. J., ed. 2006. The Rhetorical Presidency of George H.W. Bush. Texas: A\&M University Press.

Nguyen, Thi Huyen Linh. 2015. New Zealand Same-Sex Marriage Legislation in the Australian Media. Continuum 29: 287-303.

Obama, B. 2006. 'Federal Marriage Amendment', Floor Statement of Senator Barack Obama June 5, 2006. URL <http://obamaspeeches.com/075-Federal-Marriage-AmendmentObama-Speech.htm>. Consulted 31 July 2015.

Obama, B. 2008. Remarks of Senator Barack Obama, 'The American Promise.' Democratic National Convention, August 28, 2008. Denver, Colorado.

Obama, B. 2010. News Conference by the President, South Court Auditorium, Eisenhower Executive Office Building, December 22, 2010. URL < https://www.whitehouse.gov/thepress-office/2010/12/22/news-conference-president>. Consulted 25 July 2015.

Obama, B. 2012. Obama Backs Same-Sex Marriage. 9 May 2012. URL

$<$ http://www.cbsnews.com/news/obama-backs-same-sex-marriage/>. Consulted 31 July 2015.

Obama, B. 2013. Inaugural Address. 21 January 2013. URL

<https://www.whitehouse.gov/the-press-office/2013/01/21/inaugural-address-presidentbarack-obama>. Consulted 30 July 2015. 
Obama, B. 2014. Remarks by the President on 'My Brother's Keeper' Initiative. The White House, February 27, 2014. URL: <https://www.whitehouse.gov/the-press-

office/2014/02/27/remarks-president-my-brothers-keeper-initiative $>$. Consulted 30 July 2015.

Obama, B. 2015. Remarks by the President on the Supreme Court Decision on Marriage Equality. Rose Garden, 26 June 2015. URL <https://www.whitehouse.gov/the-press-office/2015 106/26/ remarks-president-supreme-court-decision-marriage-equality>. Consulted 30 July 2015.

Okin, S. 1989. Justice, Gender, and the Family. New York: Basic Books.

Olsen, K.A. 2014. Telling our Stories: Narrative and Framing in the Movement for Same-Sex Marriage. Social Movement Studies 13: 248-266.

Packham, B. and Kerr, C. 2012. Senator Cory Bernardi Quits After 'One Mistake Too Many.' The Australian, 19 September. URL <http://www.theaustralian.com.au/nationalaffairs/cory-bernardi-quits-over-bestiality-comments/story-fn59niix-1226477232022>. Consulted 21 May 2015.

Pierson, P. 2004. Politics in Time. History, Institutions and Social Analysis. Princeton: Princeton University Press.

Pierceson, J. 2014. Same-sex Marriage in Canada and the United States: The Role of Political and Legal Culture. American Review of Canadian Studies 44: 321-333.

Schmidt, V.A. 2008. Discursive Institutionalism: The Explanatory Power of Ideas and Discourse. Annual Review of Political Science 11: 303-326.

Schmidt, V.A. 2010. Taking Ideas and Discourse Seriously: Explaining Change through Discursive Institutionalism as the Fourth 'New Institutionalism.' European Political Science Review 2: 1-25.

Sherkat, D. E., de Vries, K. M. and Creek, S. 2010. Race, Religion, and Opposition to Same-Sex Marriage. Social Science Quarterly 91: 80-98.

Shumway, D. 2003. Modern Love: Romance, Intimacy and the Marriage Crisis. New York: New York University Press.

Skinner, Q. 2007. Paradiastole: Redescribing the Vices as Virtues. In S. Adamson, G. Alexander and K. Ettenhuber, eds. Renaissance Figures of Speech. Cambridge: Cambridge University Press.

Stone, L. 1977. The Family, Sex and Marriage in England 1500-1800. London: Weidenfeld and Nicolson. 
Toye, R. 2011. The Rhetorical Premiership: a new perspective on prime ministerial power since 1945. Parliamentary History 30: 175-92.

Tulis, J. 1987. The Rhetorical Presidency. Princeton: Princeton University Press.

Uhr, J. and Walter, R. eds. 2014 Studies in Australian Political Rhetoric. Canberra: ANU Press.

Uhr, J. and Walter, R. 2015. The Rhetorical Standards of Public Reason in Australia.

Australian Journal of Politics and History 61: 248-262.

van Acker, E. 2017 (forthcoming). Marriage and Values in Public Policy: Conflicts in the UK, the US and Australia. New York: Routledge.

Watt, N. 2013. Labour Saves David Cameron's Gay Marriage Bill. The Guardian, 21 May 2013. URL < http://www.theguardian.com/society/2013/may/21/labour-cameron-gaymarriage-bill>. Consulted 30 July 2015.

\footnotetext{
'There are many ways to characterise this process of contestation through argument. For example, one form of re-framing is paradiastole, which has been interpreted as the rhetorical re-description of a vice as a virtue (see Skinner 2007).
} 